\title{
Crop Production System and Their Constraints in East Shewa Zone, Oromia National Regional State, Ethiopia
}

\author{
Asfaw Negesse Senbeta, Shimalis Gizachew Daselegn, Yassin Esmael Ahmed, Beriso Bati Bukul \\ Departments of Agricultural Economics, Adami Tulu Agricultural Research Centre, Oromia Agricultural Research Institute, Ethiopia

\section{Email address} \\ bonsahu@gmail.com (A. N. Senbeta), shimegiz2006@gmail.com (S. G. Daselegn), yasoesmae@gmail.com (Y. E. Ahmed), \\ batiberis@gmail.com (B. B. Bukul)
}

\section{To cite this article:}

Asfaw Negesse Senbeta, Shimalis Gizachew Daselegn, Yassin Esmael Ahmed, Beriso Bati Bukul. Crop Production System and Their Constraints in East Shewa Zone, Oromia National Regional State, Ethiopia. International Journal of Energy and Environmental Science. Vol. 5, No. 2, 2020, pp. 30-39. doi: 10.11648/j.ijees.20200502.11

Received: October 16, 2019; Accepted: April 15, 2020; Published: April 30, 2020

\begin{abstract}
Crop production is a complex combination of inputs which influenced by environmental, economical, institutional, political and social factors. Targeted extension for heterogeneous farming systems is a challenge in developing countries. Crop production characterization based on agro-ecology, production system and different farm components helps to identify area specific problems and give proper technological intervention to address the problems. Therefore, this study was initiated to characterize cropping system in East Shewa Zone with the objectives of identifying and characterizing the existing cropping systems, identify and prioritize constraints of crop production for identifying potential research interventions. Both Primary and secondary data collection method was used. Multi-stage sampling technique was employed to select sampled districts, PAs and household farmers. Primary data was collected by conducting Focus Group Discussion (FGD), key informant interview and household's interview by using semi-structured questionnaires. A total of 184 sample households were interviewed. Descriptive statistics was used to analyze the collected data using STATA version 14. The study finds out that East Shewa Zone practices rain feed and irrigation based cropping systems. Irrigation based crop production system that dominated by onion-tomato based production system and rain-fed based farming system which classified into maize-Teff based and haricot bean-chickpea based production systems. Major agricultural production constraints within the crop production systems of Zone are identified and the possible policy implications are suggested to solve the identified problems.
\end{abstract}

Keywords: Constraints, East Shewa Zone, Crop Production System, Identification and Characterization

\section{Introduction}

\subsection{Background and Justification}

The agriculture sector is the most important segment in the Ethiopian economy. This is because of its contribution to the national GDP (38.5\%) where crop accounted for $27.4 \%$, and provides employment for $72.7 \%$ of the total population. The performance of major crops has been the major contributor to overall growth in agriculture and allied activities during GTP-I plan period given its relative importance in crop production and agriculture at large [1].

According to [2], a farming system is defined as a population of individual farm systems that have broadly similar resource bases, enterprise patterns, household livelihoods and constraints, and for which similar development strategies and interventions would be appropriate. The classification of the farming systems of developing regions has been based on the following criteria: available natural resource base, including water, land, grazing areas and forest; climate, of which altitude is one important determinant; landscape, including slope; farm size, tenure and organization; and dominant pattern of farm activities and household livelihoods, including field crops, livestock, trees, aquaculture, hunting and gathering, processing and off-farm activities; and taking into account the main technologies used, which determine the intensity of production and integration of crops, livestock and other activities.

Smallholders operating one or more parcels of land, ranging from very small blocks of less than 0.25 ha to 25 ha of land on rare occasions, represent the majority of farmers in 
Ethiopia [3, 4] Classified 72 global farming systems in six developing regions where smallholder production systems dominate livelihood patterns. They define a farm system as the household, its resources, and the resource flows and interactions at the individual farm level.

Many factors influence the variability in production across farming systems. Amongst them, climate variability has a high degree of influence on production in Ethiopian farming systems, particularly in drought prone areas. Recent studies have revealed that there has not been a significant change in rainfall amount during annual Kiremt and Bleg seasons over the last 30 years [5]. However, there has been a significant change in rainfall variability over the same period, particularly in the low-lying pastoral and agro-pastoral farming systems.

Farming systems research is an approach for generating appropriate technologies for studying existing farming systems and involving the technology users - usually the small farmers in the planning and evaluation process. Thus, study of farm typology is of practical interest for precise and effective technological interventions. Farm typology study recognizes that farmers are not a monolithic group and face differential constraints in their farming decisions depending on the resources available to them and their lifestyle $[6,7]$ Observes that small farmers are always and everywhere typified by internal variations along many lines. Although every farm and farmer is unique in nature, they can be clustered into roughly homogeneous groups. Developing a typology constitutes an essential step in any realistic evaluation of constraints and opportunities that farmers face and helps forwarding appropriate technological solutions, policy interventions $[8,9]$ and comprehensive environmental assessment [10].

According to [11] the approach is justified on the basis of three vital considerations. Firstly, the farmer and his family are rational in their decision-making. Given their available resource base, circumstances, opportunities and knowledge, they typically manage a combination of crops, animals, and other on-farm and off-farm activities to satisfy basic physical, financial and social needs. Secondly, the production systems of small farmers embody an integrated set of husbandry practices that have developed over centuries so that these systems are stable, complex and very sensitive to the ecological, biological and socio-economic. Thirdly, a farming system belongs to the goal-setting and purposeful category of systems and its direction is determined by the farmer and his family. Hence, it is very important to characterize, analyze the crop production system of the area in the arena of multistakeholders perspectives. Thus this activity intends to understand the potential and constraints of crop production system of the area.

\subsection{Statement of the Problems}

Farming system of Ethiopia constitutes a complex production unit involving a diversity of mixed crops and livestock in order to meet the multiple objectives of the households. The combination of these activities depends on environmental conditions, resource endowment and the management skill of the farmer. Climate change is expected to affect agriculture, food security and nutrition unevenly across countries and regions and it is dynamics in nature [12].

Understanding the crop production system and maintaining the balance in the complex set of farmer's objectives are pertinent to outlining promising development strategies for such system. Knowing about the crop production system is also crucial to generate an appropriate technology that improves the livelihood of farming community and ensure food security. Most of the time proposed plans and programs without detail knowledge of the crop production system of the area leads to wastage of resources and incompatible with farmer's needs. So knowing crop production of one area is very important to recommend appropriate technologies to the farmer. It also helps biological researcher to design appropriate and problem addressing agricultural technologies that fit to the environment which is also important for further agricultural research and development.

The purposes of this study is to understand and describe the resource endowment, environmental, and biological circumstances and it also describe crop production practices, prioritize major constraints, and suggest possible technology interventions in the area.

\subsection{Objectives}

General objective of this study was to characterize and analyze the smallholders' existing crop production systems of the area.

The specific objectives were:

1. To identify and characterize the existing crop production systems of the East Shewa Zone.

2. To identify and prioritize the constraints of crop production system in study area.

3. To identify farmers' perception towards change in crop production systems in East Shewa Zones.

\section{Research Methodology}

\subsection{Description of the Study Areas}

The research was conducted in East Shewa Zone. East Shewa Zone lies between $6000^{\prime} \mathrm{N}$ to $7035^{\circ} \mathrm{N}$ and $38000^{\prime} \mathrm{E}$ to 40000 'E. This zone is bordered on the South by the West Arsi Zone, on the Southwest by the Southern Nations, Nationalities and Peoples Region, on the West by South West Shewa Zone, on the Northwest by North Shewa, and on the Southeast by Arsi Zone. Adama city is the capital city of East Shewa Zone and located at $100 \mathrm{~km}$ from Addis Ababa towards South-East direction [13].

East Shewa Zone has different agro-ecologies which categorized as highland, midland and lowland agroecologies. In the Zone, $18.70 \%$ of the agro-ecology is high land, $27.50 \%$ is midland and $53.80 \%$ is lowland. The total population in the Zone was1, 275,645 of which $53.26 \%$ are male and $46.74 \%$ are female. The Zone received $350 \mathrm{~mm}$ - 
$1150 \mathrm{~mm}$ annual rain fall and has uni-modal nature of rain fall pattern. This Zone was received $12^{\circ} \mathrm{C}-39^{\circ} \mathrm{C}$ annual temperature per year. The Zone has a total of 971,159.21 hectare of land. From the total land, $12.57 \%$ is arable land, $47.31 \%$ is cultivated land, $4.18 \%$ forest land, $14.58 \%$ grazing land, $4.89 \%$ is used for construction and $12.82 \%$ is used for other purposes [13].

\subsection{Sampling Procedures and Sample Size}

Multi-stage sampling procedure was applied to select representative districts, PAs and sample households in East Shewa Zone. On the basis of agro-ecology diversity, representative districts, PAs and sample household was selected using systematic sampling technique. From the selected PAs, sample households were randomly selected for data collection. A multi-disciplinary team was established to conduct the survey using different PRA tools. Different PRA tools like direct interview, focus group discussions and personal observations were employed to collect information on different aspects of existing crop production systems of the study area. Focus group discussion and key informant interview were employed to get about the existing crop production system, prevailing constraints, with key informants (farmers, Development agents, and community leaders) in the study areas. Finally, 184 sample households were selected for primary data collection.

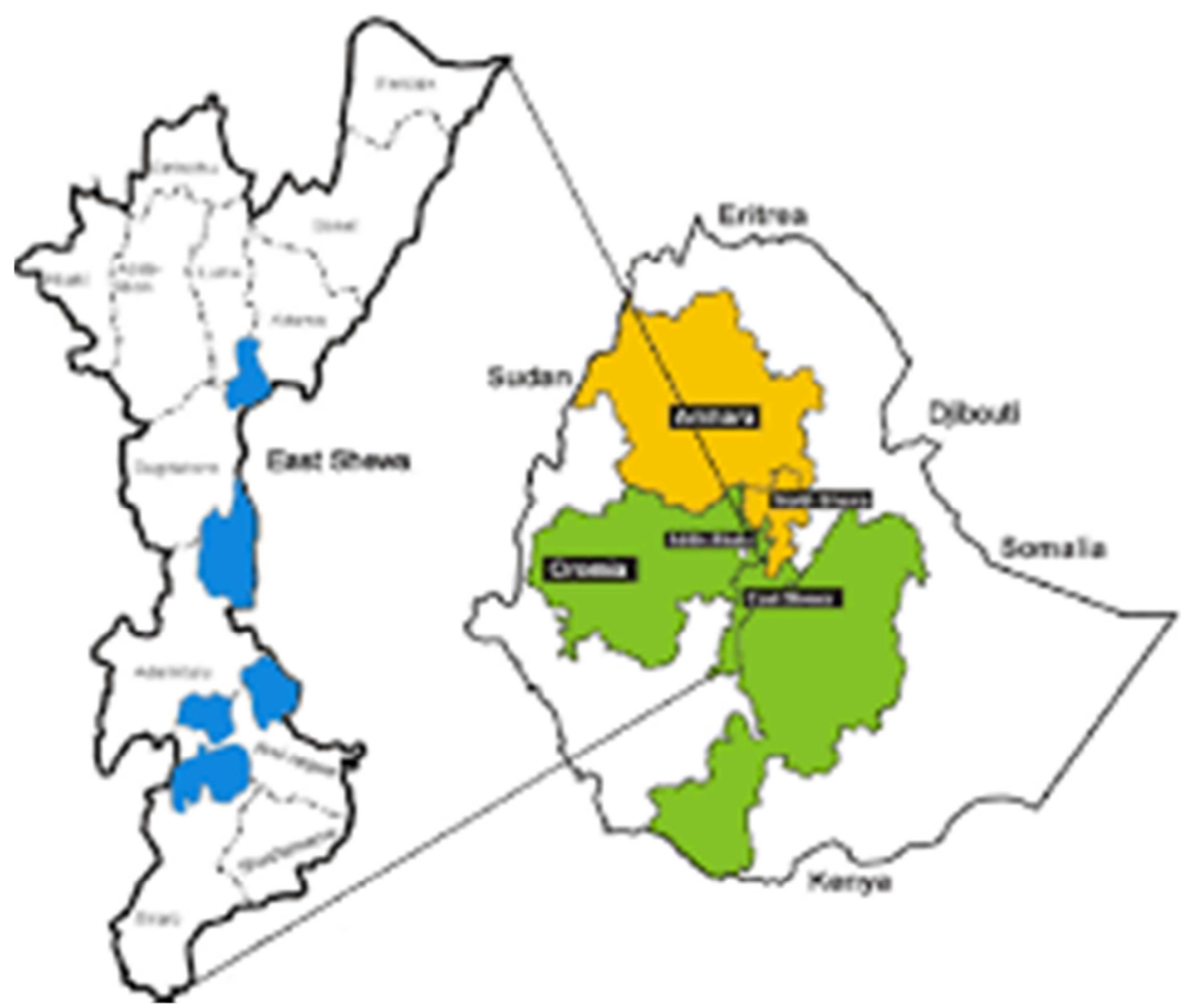

Figure 1. Map of East Shewa Zone.

Table 1. Number of sample households in East Shewa Zone.

\begin{tabular}{lll}
\hline Names of Districts & Frequency & Percentage \\
\hline Adama & 53 & 28.80 \\
Adami Tulu & 62 & 33.70 \\
Fantale & 21 & 11.40 \\
Lume & 48 & 26.10 \\
Total & 184 & 100 \\
\hline
\end{tabular}

Source: Survey result, 2016.

\subsection{Types of Data, Sources and Method of Data Collection}

Both quantitative and qualitative type of data was used. Both primary and secondary data was collected from different sources at different levels. Primary data was collected through focus group discussions, key informant interview and households' interview using checklist and semi-structured questionnaire. Secondary data were collected from different agricultural and natural resource development offices, livestock agency, trade and market development office, irrigation offices at different levels (Zone, districts, and PAs), different NGOs and stakeholders working in the areas, CSA reports, and different un published reports.

\subsection{Methods of Data Analysis}

The collected data was analyzed using STATA version 14 software. The quantitative and qualitative data was analyzed using descriptive statistics like mean, standard deviations, and frequency. The qualitative data collected through FGD and KII was also analyzed by narrating methods. 


\section{Results and Discussion}

\subsection{Socio-economic Characteristics and Resource Ownership of Households}

In the crop production system analysis socio-economics factor and household resource endowments play an important role in identifying and characterizing the crop production system of a given area. The socio-economics characteristics included age of household, marital status, education background, total family size, labor availability, and participation in non-farm and off-farm activities under this study. About $80 \%$ of sample respondents were male headed household. The majority (40\%) of the sample households are illiterate in followed elementary education. About $88 \%$ of responders were married. In the study areas, farmers were categorized as model, middle, and resource poor based on their wealth status (Table 2).

Table 2. Description of categorical variables of sample households.

\begin{tabular}{|c|c|c|c|c|c|c|c|c|c|c|c|}
\hline \multirow{3}{*}{ Variables } & \multirow{3}{*}{ Category } & \multicolumn{10}{|c|}{ Districts } \\
\hline & & \multicolumn{2}{|c|}{ Adama $(n=53)$} & \multicolumn{2}{|c|}{ Adami Tulu $(n=62)$} & \multicolumn{2}{|c|}{ Fantale $(n=21)$} & \multicolumn{2}{|c|}{ Lume $(n=48)$} & \multicolumn{2}{|c|}{ Over all $(n=184)$} \\
\hline & & Freq & $\%$ & Freq & $\%$ & Freq & $\%$ & Freq & $\%$ & Freq & $\%$ \\
\hline \multirow{4}{*}{ Sex } & Male & 45 & 84.90 & 52 & 83.87 & 17 & 80.95 & 34 & 70.83 & 148 & 80.43 \\
\hline & Female & 8 & 15.10 & 10 & 16.13 & 4 & 19.05 & 14 & 29.17 & 36 & 19.57 \\
\hline & Illiterate & 25 & 47.17 & 16 & 25.81 & 14 & 66.67 & 18 & 37.5 & 73 & 39.67 \\
\hline & Read and Write & 7 & 13.21 & 5 & 8.00 & 1 & 4.76 & 5 & 10.42 & 18 & 9.78 \\
\hline \multirow{3}{*}{$\begin{array}{l}\text { Education } \\
\text { status }\end{array}$} & Elementary (1-8) & 15 & 28.30 & 36 & 58.06 & 3 & 14.29 & 18 & 37.5 & 72 & 39.13 \\
\hline & High School (9-12) & 6 & 11.32 & 3 & 4.84 & 1 & 4.76 & 6 & 12.5 & 16 & 8.70 \\
\hline & College/University & & & 2 & 3.22 & 2 & 9.52 & 1 & 2.08 & 5 & 2.71 \\
\hline \multirow{4}{*}{ Marital status } & Single & 4 & 7.75 & 4 & 6.45 & 2 & 9.52 & 6 & 12.5 & 16 & 8.70 \\
\hline & Married & 46 & 86.79 & 56 & 90.32 & \multirow{3}{*}{19} & \multirow{3}{*}{90.48} & 41 & 85.42 & 162 & 88.04 \\
\hline & Widowed & 3 & 5.66 & 1 & 1.61 & & & 1 & 2.08 & 5 & 2.72 \\
\hline & Divorced & & & 1 & 1.61 & & & & & 1 & 0.54 \\
\hline
\end{tabular}

Sources: Household survey result, 2016.

As showed in the following Table 3, the mean age of the sampled households was 41 years. The mean family member per household was about 7 per family member which was in line with finding of [14]. The mean land holding and cultivated land of the farm households is about 2.24 and 1.51 hectare in per household which is greater than national average of 1.57 and 0.95 hectares respectively [15]. The result is in lined with the findings of [16] which states that mixed farming system is about $1-2$ ha. In Wollaita zone and the average landholding is less than 0.75 ha per family of seven.

Table 3. Description of continues variables of sample households.

\begin{tabular}{llll}
\hline & & \multicolumn{2}{l}{ Over all (n=184) } \\
\hline No & Variables & Mean & Std. Dev. \\
\hline 1 & Age & 41.39 & 14.63 \\
2 & Total Family size & 7.04 & 3.61 \\
3 & Total land holding (ha) & 2.24 & 1.92 \\
4 & Total cultivated land (ha) & 1.51 & 1.05 \\
\hline
\end{tabular}

Sources: Household survey result, 2016.

\subsection{The Land Use Patterns}

Land is one of an important input in agricultural production. The study result revealed that the sampled households are allocated more lands for cultivation purpose (Table 4). In addition to this, they also allocated their lands for forest and grazing lands. The land degradation was also occurred due to miss-use of the land in the study areas. From focus group discussion and household level survey, there is no communal grazing land except in pastoral/agro-pastoral areas like Fentale district. A significant proportion of crop production was harvest by using rain fed agriculture whereas a small amount of crop production was harvested from irrigation based production. This is due to sufficient unavailability of irrigation water in East Shewa Zone.

Table 4. The households land use system.

\begin{tabular}{lll}
\hline \multirow{2}{*}{ Variables } & \multicolumn{2}{l}{ Over all $(\mathbf{n = 1 8 4})$} \\
\cline { 2 - 3 } & Mean & Std. Dev. \\
\hline Land cultivated by rain fed & 1.30 & 0.96 \\
Land cultivated by irrigation & 0.02 & 0.10 \\
Land for grazing & 0.10 & 0.21 \\
Erosion affected land & 0.01 & 0.06 \\
Forest land & 0.01 & 0.07 \\
Homestead land & 0.29 & 0.39 \\
\hline
\end{tabular}

Sources: Household survey result, 2016.

\subsection{Households' Participation in Off/Non-Farm Activities}

The farmers in the study areas engaged in farm (crop and livestock) and off/non-farm activities to diversify and improve their livelihoods. The Household's participated in off/non-farm activities in East Shewa Zone to generate income. The off/non-farm activities that households engaged to generate additional incomes are work as labor (causal) on other's farm activity, trade, salaried worker as guard, petty trade and driving carts. The households participated more in trades (crop and livestock) to generate additional income in the study areas (Table 5).

Table 5. The type of off/non-farm activities performed in the study areas.

\begin{tabular}{lll}
\hline \multirow{2}{*}{ Off/non-farm activities } & \multicolumn{2}{l}{ Over all $(\mathbf{n = 1 8 4})$} \\
\cline { 2 - 3 } & Frequency & Percent \\
\hline Casual farm labor & 3 & 14.29 \\
Salaried worker as guard & 7 & 33.33 \\
Traders (crop and livestock) & 8 & 38.10 \\
\hline
\end{tabular}




\begin{tabular}{lll}
\hline \multirow{2}{*}{ Off/non-farm activities } & Over all $(\mathbf{n}=\mathbf{1 8 4})$ & \\
\cline { 2 - 3 } & Frequency & Percent \\
\hline Petty trade & 1 & 4.76 \\
Driving carts & 1 & 4.76 \\
\hline
\end{tabular}

Sources: Household survey result, 2016.

\subsection{Institutional Facilities for Agricultural Production in East Shewa Zone}

The institutional factors play a crucial role to increase agricultural production. These institutional facilities are irrigation facilities, communication facilities, extension services, credit facilities and market services. About $91 \%$ of respondents not use credit service because of different reasons such as in appropriate payback period; religious view and no need. More than half of respondents get extension service about $86 \%$ as a result of available to development agent at Peasant Association level. About $61 \%$ of respondent not get market information due to limitation of information providers. Only $39 \%$ get market information by using mobile phone and from each other (Table 6).

Table 6. Institutional facilities in East Shewa Zone.

\begin{tabular}{llll}
\hline Variables & Number of Sample $(\mathbf{n = 1 8 4})$ & & Freq \\
\hline & & 167 & 90.76 \\
\hline Credit services & No & 17 & 9.24 \\
& Yes & 25 & 13.59 \\
Extension services & No & 159 & 86.41 \\
& Yes & 112 & 60.87 \\
Market information & No & 72 & 39.13 \\
& Yes & & \\
\hline
\end{tabular}

Sources: Household survey result, 2016.

\subsection{Households' Farm Labor Availability}

Many of the subsistence farming used family labor for agricultural production. The majority of the farmers in the study areas used family for agricultural production. The farmers in the study areas used labor exchange, employing casual labor, and hired labor during labor shortage and busy working time.

Table 7. Labor availability in East Shewa Zone.

\begin{tabular}{lll}
\hline \multirow{2}{*}{ Variable } & \multicolumn{2}{l}{ East Shewa Zone } \\
\cline { 2 - 3 } & Mean & Std. Dev \\
\hline Labor equivalent & 4.98 & 2.69 \\
\hline
\end{tabular}

Sources: Household survey result, 2016.

\subsection{The crop production System of East Shewa Zone}

East Shewa Zone practiced both irrigation based crop production system and rain fed based crop production system. These sub-cluster farming system are Onion-Tomato based crop production system, Maize-Teff based crop production system and Haricot bean-Chickpea based crop production system. The onion-tomato based crop production system is widely practiced in irrigation available areas where as MaizeTeff based crop production system and Haricot bean-Chickpea based crop production system are practiced under rainfall. There is also further clustering based on number of cropping per a year as double cropping and single cropping. Almost all mixed crop-livestock crop production system practiced single cropping while irrigation based farming practiced double cropping and even triple cropping by using irrigation.

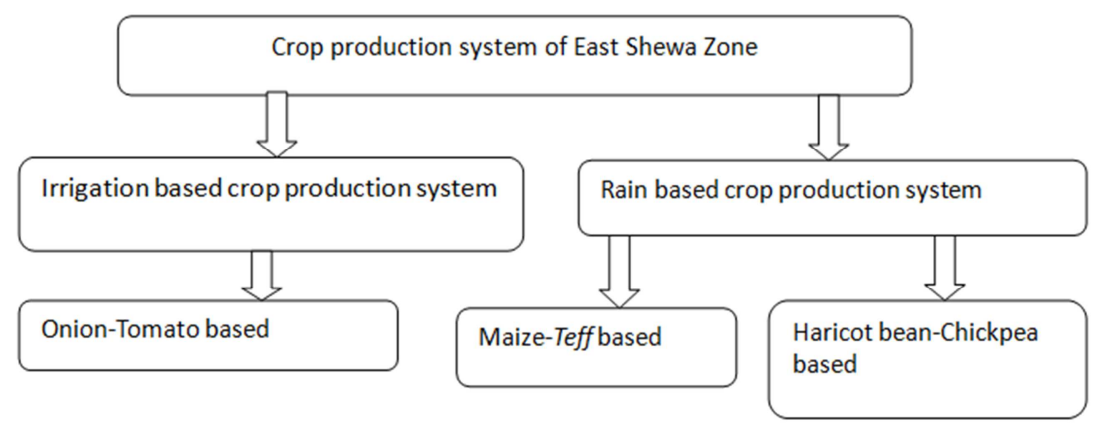

Figure 2. Characterizations of crop production system in East Shewa Zone.

\subsection{Characteristics of Sub-Clusters Crop Production System in East Shewa Zone}

Under this crop production system onion-tomato based farming system, maize-Teff based farming system, and haricot bean-Chickpea based farming system with their respective constraints are discussed in detail.

\subsubsection{Onion-tomato Based Crop Production System}

This crop production system was widely practiced in 
lowlands of Adami Tulu, Dugda, Bora and Fentale districts where irrigation is available. The major crops produced in this sub-cluster in addition to onion and tomatoes are hot pepper, cabbage (Ethiopian Kale), snap bean (Fosolia) and haricot bean. Maize production was also undertaken in small amount in this cluster. The majority irrigation user farmers used traditional irrigation system like flooding. Onion is the first leading cash crop produced in large amount in this subcluster farming system whereas tomato is the second major cash crop produced next to onion.

From the total landing, about $40 \%$ of the land allocated for onion production. The tomato production was also shares about $28 \%$ of total land. The mean onion production was 80 quintal per hectare while tomato was 42.32 quintal per hectare. The households produced onions and tomatoes majorly for marketing and for home consumption. From total sample households, $57.14 \%$ of the respondents perceived that the trends of onion production in the past five years is increasing and about $42.86 \%$ of the respondents perceived that the trends of tomato production in the past five years is decreasing. The probable reason for the decline of tomato production was the outbreak of pests (Tuta Absoluta), shortage of disease resistance varieties and high input costs.

\subsubsection{Major Production Constraints Onion-tomato Crops Based Crop Production System}

The onion-tomato based crop production system was widely undertaken in the lowland agro-ecology of East Shewa Zone where irrigation is available. This farming system was mainly undertaken in Adami Tulu Jido kombolcha and Fentale districts of East Shewa Zone. The onion-tomato based farming system was challenged by different factors like other farming system. The major constraints inthe onion-tomato based farming system are lack of credit and cash, shortage of improved seed, market problems (lack of market information and high price of inputs), untimely supply of agricultural technologies (fertilizers and chemicals), disease, climate change (drought and erratic rain fall), lack of storage and low soil fertility (Table 8). Index ranking was employed to prioritize the major production constraints of this farming system.

Table 8. Major production constraints in onion-tomato based crop production system.

\begin{tabular}{|c|c|c|c|c|c|c|c|c|c|c|}
\hline \multirow{2}{*}{ No. } & \multirow{2}{*}{ Constraints } & \multicolumn{2}{|l|}{$1^{\text {st }}$} & \multicolumn{2}{|l|}{$2^{\text {nd }}$} & \multicolumn{2}{|l|}{$3^{\text {rd }}$} & \multicolumn{2}{|l|}{$4^{\text {th }}$} & \multirow{2}{*}{ Index rank } \\
\hline & & Freq. & $\%$ & Freq. & $\%$ & Freq. & $\%$ & Freq. & $\%$ & \\
\hline 1 & Lack of credit and cash & 15 & 18.07 & 15 & 18.29 & 18 & 23.38 & 15 & 25.42 & 1 \\
\hline 2 & Shortage of improved seed & 20 & 24.10 & 13 & 15.85 & 7 & 9.09 & 10 & 16.95 & 2 \\
\hline 3 & Market problems & 9 & 10.84 & 14 & 17.07 & 15 & 19.48 & 5 & 8.47 & 3 \\
\hline 4 & $\begin{array}{l}\text { Lack of supply agricultural technology } \\
\text { on time }\end{array}$ & 13 & 15.66 & 13 & 15.85 & 10 & 12.99 & 6 & 10.17 & 4 \\
\hline 5 & Disease & 17 & 20.48 & 8 & 9.76 & 7 & 9.09 & 3 & 5.08 & 5 \\
\hline 7 & Lack of storage & 2 & 2.41 & 4 & 4.88 & 6 & 7.79 & 4 & 6.78 & 7 \\
\hline 8 & Low soil fertility & 1 & 1.20 & 3 & 3.66 & 2 & 2.60 & 2 & 3.39 & 8 \\
\hline
\end{tabular}

Sources: Household survey result, and FGD result, 2016.

\subsubsection{Maize-Teff Based Crop Production System}

The high land, midland and lowland areas of East Shewa Zone are known by maize and Teff production [10]. The Maize-Teff based farming system was widely practiced in Lume, Adea, Adama, and Adami Tulu Jido Kombolcha Districts of East Shewa Zone. The major crops produced in this sub-cluster farming system in addition to Teff and maize production are wheat, barley and haricot bean based on the proportion of land allocation. The mean land allocated for Ted was 0.98 hectare that shares $65 \%$ of the total cultivated land and 0.875 hectare for maize production which shares $58 \%$ of the total cultivated land in the area. Livestock production was also undertaken in this subcluster farming system for diversify the livelihood of the households.

\subsubsection{Major Production Constraints in Maize-Teff Based Crop Production System}

This sub-cluster of farming system was widely practiced in highland and midlands of East Shewa Zone. In this farming system, eight production constraints were identified and ranked according to their severities. In Maize-Teff base farming system the major constraint were lack of credit and cash, lack of market information, untimely of agricultural technologies (fertilizers and chemicals), shortage of improved seed, disease, shortage and unevenly distributed of rain fall, low soil fertility, and lack of mechanized agriculture (Table 9). The majority of the households are challenged by lack of credit and cash, lack of market information, and untimely supply of agricultural technologies (fertilizers and chemicals) in crop production. This implies that an intervention required on these problems to increase crop production in the study areas.

Table 9. Major crop production constraints in maize-Teff based farming system.

\begin{tabular}{|c|c|c|c|c|c|c|c|c|c|}
\hline \multirow{2}{*}{ Constraints } & \multicolumn{2}{|l|}{$1^{\text {st }}$} & \multicolumn{2}{|l|}{$2^{\text {nd }}$} & \multicolumn{2}{|l|}{$3^{\text {rd }}$} & \multicolumn{2}{|l|}{$4^{\text {th }}$} & \multirow{2}{*}{$\begin{array}{l}\text { Index } \\
\text { rank }\end{array}$} \\
\hline & Freq. & $\%$ & Freq. & $\%$ & Freq. & $\%$ & Freq. & $\%$ & \\
\hline Lack of credit and cash & 47 & 26.55 & 36 & 23.53 & 28 & 22.05 & 26 & 27.37 & 1 \\
\hline Market problems & 16 & 9.04 & 33 & 21.57 & 22 & 17.32 & 18 & 18.95 & 2 \\
\hline
\end{tabular}




\begin{tabular}{|c|c|c|c|c|c|c|c|c|c|}
\hline \multirow{2}{*}{ Constraints } & \multicolumn{2}{|l|}{$1^{\text {st }}$} & \multicolumn{2}{|l|}{$2^{\text {nd }}$} & \multicolumn{2}{|l|}{$3^{\text {rd }}$} & \multicolumn{2}{|l|}{$4^{\text {th }}$} & \multirow{2}{*}{$\begin{array}{l}\text { Index } \\
\text { rank }\end{array}$} \\
\hline & Freq. & $\%$ & Freq. & $\%$ & Freq. & $\%$ & Freq. & $\%$ & \\
\hline Shortage of improved seeds & 33 & 18.64 & 26 & 16.99 & 16 & 12.60 & 10 & 10.53 & 3 \\
\hline Untimely of supply of agricultural technology & 31 & 17.51 & 21 & 13.73 & 20 & 15.75 & 11 & 11.58 & 4 \\
\hline Disease & 32 & 18.08 & 17 & 11.11 & 19 & 14.96 & 4 & 4.21 & 5 \\
\hline Climate change & 14 & 7.91 & 12 & 7.84 & 17 & 13.39 & 14 & 14.74 & 6 \\
\hline Low soil fertility & 4 & 2.26 & 6 & 3.92 & 2 & 1.57 & 5 & 5.26 & 7 \\
\hline Lack mechanized agriculture & & 0.00 & 2 & 1.31 & 3 & 2.36 & 7 & 7.37 & 8 \\
\hline
\end{tabular}

Source: Household survey result and secondary data report, 2016.

\subsubsection{Haricot Bean-chickpea Based Crop Production System}

Chickpea and haricot bean are widely produced in East Shewa Zone [9]. The haricot bean-Chick pea based farming system was widely practiced in midland of Adea, Libean cukala, Gimbichu and Lume districts of East Shewa Zone. The mean land allocated for chickpea and haricot bean production was 0.5 hectare and 0.48 hectare respectively. The major crops produced in this sub-cluster farming system next to chickpea and haricot bean production are lentils, wheat, barley, maize, Teff and linseed. Livestock production was also undertaken in this farming system for diversifying the livelihood of the farmers.

\subsubsection{Major Production Constraints of Haricot Bean-Chick Pea Based Crop Production System}

There are different crops produced in this crop production system. The major constraints in this sub-cluster of farming system were identified and ranked based on their appearance in the study areas (Table 10). These constraints are lack of credit and cash, market problems (market information, high input prices and low market price of outputs), untimely supply of agricultural technologies (fertilizers and chemicals), shortage of improved seed and disease resistance varieties, disease, climate change (erratic rain fall and drought), and lack of mechanized agriculture. According to the respondents the crop disease occurred due to shortage of chemicals, untimely supply of chemicals according to the requests and lack disease resistance varieties

Table 10. Major production constraints in haricot bean-chickpea based crop production system.

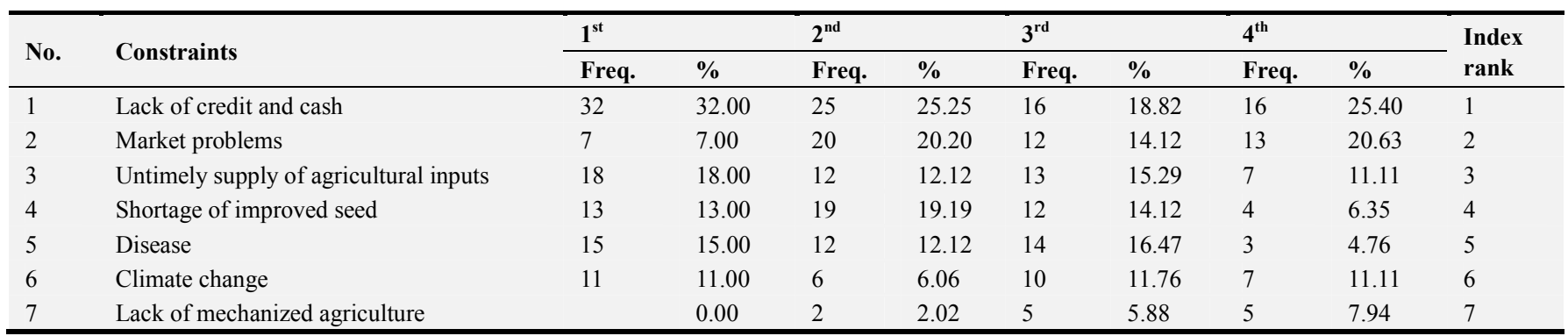

Source: Household survey result, and secondary data report, 2016.

\subsection{Farmers' Perception towards Change in Crop Production Systems in East Shewa Zone}

Land is an important input factor in agricultural production. However, the farmers faced shortage of land in East Shewa Zone. The main causes of land shortage were an alarming rate of population growth and expansion of cultivation land. The sampled households mean land holding in East Shewa Zone is 2.31 hectare respectively. Population growth and expansion of cultivation land leads to shortage of grazing and deforestation which result in ozone depletion that causes global warming. Therefore, an intervention is required especially on intensification farming and awareness creation on forest conservation in the zones.

Land shortage limited households to operate on small farms which may cause low crop production. Low crop production leads to shortage of food supply and income. Hence intensify farming system and engage in off/non-farm activities are a good option for reducing food shortage and income problems. There are different measures taken by the farmers to offset the land shortage and increase production under conditions of land shortage. Those measures are use of fertilizers and improved seeds, compost and manure, crop rotation, share cropping, land renting which accounts $37 \%$ East Shewa Zone.

In East Shewa Zone, $20.65 \%, 62.50 \%$, and $16.85 \%$ of the households perceived that trends of crop production is increasing, decreasing and fluctuating respectively since five years. This indicated that the nature of farming system changes from time to time due to different factors. The cause for increasing in agricultural production was training and advices obtained from development agents and other bodies on production inputs (fertilizer, improved seeds and livestock breeds, and pesticides), agronomic practices (land preparation, row planting, and weed management) and few mechanization technologies in cop and livestock production. However, the reduction in agricultural production was due to mono cropping, unavailability of inputs at required time and required amount, shortage of quality and diseases resistance varieties, and climate change (drought and erratic rain fall) in 


\section{East Shewa Zone.}

The dynamism in crop production system in East Shewa Zone occurred due to change in climate, shifting from one enterprise (livestock to crop) to another due to awareness created and production goal (from household consumption to market oriented production) and shift in enterprise due to continuous disease and pest occurrence. Most farmers change their whole dependence on agriculture and shift to off/nonfarm activities like petty trade because of frequent crop failure, farmland shortage and search for better living standards in urban areas.

\subsection{Cropping system, Agricultural Technologies and Mechanization in East Shewa Zone}

The production system in East Shewa Zone had both rain fed and irrigation. Sole cropping is dominantly practiced in East Shewa Zone (Table 11). This practice brought soil infertility problem which leads to low crop production. The other cropping system like intercropping, mixed cropping, and crop rotation are also practiced in Zone (Table 11). Maize relayed with Teff haricot bean, and chickpea and it intercropped with haricot bean and with sorghum sometimes.

Table 11. The type of cropping system practiced in East Shewa Zone.

\begin{tabular}{ll}
\hline Cropping system & East Shewa Zone (\%) \\
\hline Intercropping & 0.76 \\
Relay cropping & 0 \\
Mixed cropping & 0.76 \\
Sole cropping & 88.64 \\
Crop Rotation & 9.85 \\
\hline
\end{tabular}

Source: household survey result, 2016.

The Absence or supply shortage of agricultural mechanization technologies were the major production constraints in all farming system of East Shewa Zone. In wheat, barley and Teff growing areas, even though farmers understood the importance of row planting, absence of row planter technologies were the major bottleneck problems during sowing in Zone. The existing chemical sprayer equipment (knapsack) which was carried on human's back is unsafe for the operator and tiresome. This leads to misapplication of chemicals which may affect crop production. Therefore, provide training for farmers on chemical application and safety, and modernizing/further mechanizing the technology was important solution to reduce misapplication of chemicals in the study areas. In areas where crop productions was high but mechanized agricultural technologies were unavailable, supplying technologies like harvesting and threshing/shelling based on the capacity and demands of the producers.

The table 12 below indicated that the farmers are using agricultural technologies in crop production. The majority of the households used different types of improved seed, row planting \& inorganic fertilizer in crop production. The few farmers used BBM to plough the land and sowing the crops. Very few numbers of farmers were also use large mechanized technologies like tractor and combiner for ploughing their lands and harvesting the crops.

Table 12. The types of Agricultural technologies used in East Shewa Zone.

\begin{tabular}{ll}
\hline Agricultural technologies & East Shewa Zone (\%) \\
\hline Improved Seed & 6.72 \\
Inorganic fertilizer utilization & 12.69 \\
BBM & 0.75 \\
Improved seed, row planting \& inorganic & 22.39 \\
fertilizer & 51.49 \\
Improved seed and inorganic fertilizer & 5.97 \\
Inorganic fertilizer and row planting & 100 \\
Total & \\
\hline
\end{tabular}

Source: Household survey result, 2016.

\subsection{Soil and Water Conservation and Soil Fertility Improvement Practices}

Land degradation in the form of soil erosion and fertility depletion is a major challenge in the Ethiopian highlands due to its adverse impacts on crop productivity, food security and natural resource conservation [17-19].

There are two major types of soil water conservation practices in East Shewa Zone. The physical soil and water conservation practice was widely practiced by farmers in the East Shewa Zone. Around 85 percent farmers used physical soil and water conservation whereas $13.12 \%$ practicing biological soil and water conservation and $1.64 \%$ practicing both physical and biological soil and water conservation on their own farm lands (Table 13). Soil bund, terraces and cutting check-dam were widely used in physical conservation while planting multi-purpose trees and grasses were among the biological types of soil and water conservation. The farmers planted grasses like elephant grass and Rhodes on their land in East Shewa Zone to protect soil erosion.

Table 13. Soil and water conservation practices in East Shewa Zone.

\begin{tabular}{ll}
\hline SWC Practices & Over all $(\mathbf{n}=\mathbf{1 8 4})$ \\
\hline Biological & 13.115 \\
Physical & 85.25 \\
Both & 1.64 \\
Total & 100 \\
\hline
\end{tabular}

Source: Household survey result, 2016.

The farmers practices different soil fertility improvement activities in East Shewa Zone. Animal manure and composts were widely used to improve soil fertility. The majority the households applied animal manure followed by compost for soil fertility improvement (Table 14).

Table 14. Soil fertility improvement practices in East Shewa Zone.

\begin{tabular}{ll}
\hline SFI Practices & Over all $(\mathbf{n}=\mathbf{1 8 4})$ \\
\hline Use animal manure (dung) & 85.19 \\
Use compost & 8.15 \\
Use crop residue & 0 \\
Use all animal manure, compost and crop residue & 6.66 \\
Total & 100 \\
\hline
\end{tabular}

Source: Household survey result, 2016. 


\section{Conclusion and Recommendations}

This chapter explains the summarized findings of the study and gives important policy recommendations on the identified gap of the study.

\subsection{Conclusion}

In East Shewa Zone crop production system was classified into irrigation based that contains onion-tomato based crop production system and rain-fed based crop production system that clustered into maize-Teff and haricot bean-chickpea based in crop production system. This study identified and ranked the major constraints that farmers encountered in agricultural production in East Shewa Zone. The major constraints that farmers faced in crop production and are Shortage of improved seed, disease incidence (rust), unavailability of agricultural technologies (fertilizers and chemicals) on time with the required amount, lack of credit and cash, market problems (market information and high input price), climate change (drought and erratic rain fall) and absence of mechanized agricultural technologies. In East Shewa Zone, $20.65 \%, 62.50 \%$, and $16.85 \%$ of the households perceived that trends of crop production is increasing, decreasing and fluctuating respectively since five years. This indicated that the nature of crop production system changes from time to time due to different factors.

\subsection{Recommendations}

The study recommendation was made based the identified gaps of the crop production system study in East Shewa Zone.

1. Agricultural office and concerned bodies should be upgrading the farmers' skills on agricultural technologies (fertilizer and chemical applications) through trainings to improve agricultural production;

2. Agricultural Engineering Research Centers should be on demonstrating the existing agricultural technologies and promote the demanded technologies to improve agricultural production;

3. The traditional agriculture is widely practiced in East Shewa Zone. This leads to low agricultural production. Therefore, any intervention that shifts traditional agricultural production to modern agriculture like modern irrigation based production is encouraged to increase production.

4. Low soil fertility is one of the major constraints that affect crop production in the study areas. Therefore, Farmers should be used Soil and water conservation practice enhance crop production and productivity in the areas;

5. Market and Trade Development Office should be strengthening farmers' linkage by linking them to input suppliers and delivering proper \& adequate market information through market information delivery network;

6. Farmers should be agro metrology based agricultural production practice identified by research to develop mitigation and coping up mechanism to adapt climate change and reduce its impact on agricultural production.

\section{References}

[1] NPC (National Plan Commission). 2016. Growth and Transformation Plan II (GTP II), National Plan Commission Volume I: Main text Addis Ababa.

[2] FAO (Food and Agriculture Organization), 2007. The state of food and agriculture. Paying farmers for environmental services, Rome, Italy.

[3] Taffesse A. S., Dorosh P. and Asrat S. 2011. Crop production in Ethiopia: Regional Patterns and Trends. At $<\mathrm{http}: /$ essp.ifpri.info/files/2011/02/ESSP2_WP16_CropProductionin-Ethiopia-Regional-Patterns-and-Trends. $\overline{p d f}>$.

[4] Dixon J. G., Gulliver A. and Gibbon D. 2001. Farming systems and poverty: Improving farmers' livelihoods in a changing world. Food and Agriculture Organization/ World Bank, Rome/Washington.

[5] Suryabhagavan K. V. 2017. GIS-based climate variability and drought characterization in Ethiopia over three decades. Weather and Climate Extremes 15, 11-23. doi: http://dx.doi.org/10.1016/j.wace.2016.11.005.

[6] Soule MJ, 2001. Soil management and the farm typology: do small family farms manage soil and nutrient resources differently than large family farms? Agric Resour Econ Rev 30: 179-188.

[7] Ellis F, 1993. Peasant Economics: Farm Households and Agrarian Development, 2nd edn. Cambridge University Press, Cambridge.

[8] Ganpat W. Bekele I, 2001. Looking For the Trees In The Forest: Farm Typology As A Useful Tool In Defining Targets For Extension. In: Lindner JR (ed) Proceedings of the 17th Annual Conference of the Association for International Agricultural and Extension Education. Baton Rouge, Louisiana. Available on http://agris.fao.org/agrissearch/search.

[9] Vanclay JK, 2005. Using a typology of tree-growers to guide forestry extension. Ann Trop Res 27: 97-103.

[10] Andersen E, 2009. Regional Typologies of Farming Systems Contexts, seamless Integrated Project, Eu 6th Framework Programme. Available. http://www.seamlessip.org/Reports/Report_53_PD4.4.3.pdf.

[11] FAO (Food and Agriculture Organization), 1980. The state of food and agriculture. World Review Marine Fisheries in the New Era of National Jurisdiction, Rome, Italy.

[12] FAO (Food and Agriculture Organization). 2019. Publications Catalogue Rome, Italy. www.fao.org/publications.

[13] ZOA. 2016. Report on major agricultural activities. East Shewa Zone, Zonal Office of Agriculture unpublished report.

[14] Tamrat Gebiso Challa, Aman Nebo Tibesso, Ashebir Tsegayie Mamo. Farming System Characterization of Arsizone: Case of Small-Scale Farming. American Journal of Environmental and Resource Economics. Vol 4 (1). doi: 10.11648/j.ajere.20190401.12.

[15] CSA (Central Statistical Agency). 2015. The Federal Democratic Republic of Ethiopia Central Statistical Agency key finding agricultural sample, surveys. 
[16] Tilahun Amede, Christopher Auricht, Jean Marc Boffa, John Dixon Tthilack, Mandi Rukani and Tilaye Teklewold Demekw. 2017. A farming system framework for investment planning and priority setting in Ethiopia, Australian centre for International Agricultural Technical reports.

[17] Laekemariam F, Kibret K, Shiferaw H (2018) Potassium (K)to-magnesium $(\mathrm{Mg})$ ratio, its spatial variability and implications to potential Mg-induced K deficiency in Nitisols of Southern Ethiopia. Agric Food Secur 7: 13.
[18] Teklu E, Williams TO, Fanuel L (2018) Integrated soil, water and agronomic management effects on crop productivity and selected soil properties in Western Ethiopia. Int Soil Water Conserv Res 6: 305-316.

[19] Adimassu Z, Langan S, Johnston R, Mekuria W, Amede T (2017) Impacts of soil and water conservation practices on crop yield, run-off, soil loss and nutrient loss in ethiopia: review and synthesis. Environ Manag 59: 87-101. 